\title{
Mats of psychrophilic thiotrophic bacteria associated with cold seeps of the Barents Sea
}

\author{
S. Grünke ${ }^{1,2}$, A. Lichtschlag ${ }^{2}$, D. de Beer ${ }^{2}$, J. Felden ${ }^{1}$, V. Salman ${ }^{2}$, A. Ramette ${ }^{1}$, H. N. Schulz-Vogt ${ }^{2}$, and A. Boetius ${ }^{1}$ \\ ${ }^{1}$ HGF-MPG Joint Research Group on Deep Sea Ecology and Technology, Alfred Wegener Institute for Polar and \\ Marine Research, Bremerhaven, Germany \\ ${ }^{2}$ Max Planck Institute for Marine Microbiology, Bremen, Germany
}

Correspondence to: S. Grünke (sgruenke@mpi-bremen.de)

Received: 2 March 2012 - Published in Biogeosciences Discuss.: 28 March 2012

Revised: 18 July 2012 - Accepted: 19 July 2012 - Published: 6 August 2012

\begin{abstract}
This study investigated the bacterial diversity associated with microbial mats of polar deep-sea cold seeps. The mats were associated with high upward fluxes of sulfide produced by anaerobic oxidation of methane, and grew at temperatures close to the freezing point of seawater. They ranged from small patches of $0.2-5 \mathrm{~m}$ in diameter (gray mats) to extensive fields covering up to $850 \mathrm{~m}^{2}$ of seafloor (white mats) and were formed by diverse sulfide-oxidizing bacteria differing in color and size. Overall, both the dominant matforming thiotrophs as well as the associated bacterial communities inhabiting the mats differed in composition for each mat type as determined by microscopy, 16S rRNA gene sequencing and automated ribosomal intergenic spacer analysis. While the smaller gray mats were associated with a highly diverse composition of sulfide oxidizers, the larger white mats were composed of only 1-2 types of gliding Beggiatoa filaments. Molecular analyses showed that most of the dominant mat-forming sulfide oxidizers were phylogenetically different from, but still closely related to, thiotrophs known from warmer ocean realms. The psychrophilic nature of the polar mat-forming thiotrophs was tested by visual observation of active mats at in situ temperature compared to their warming to $>4{ }^{\circ} \mathrm{C}$. The temperature range of mat habitats and the variation of sulfide and oxygen fluxes appear to be the main factors supporting the diversity of mat-forming thiotrophs in cold seeps at continental margins.
\end{abstract}

\section{Introduction}

At cold seeps, hydrocarbon-rich muds, brines and gases are transported from the subsurface to the seafloor and into the hydrosphere (Milkov, 2000; Dimitrov, 2002; Judd et al., 2002; Hovland et al., 2005; Cathles et al., 2010). Anaerobic oxidation of methane (AOM) coupled to sulfate reduction in near-surface sediments provides high fluxes of sulfide to the seafloor (Boetius et al., 2000). Thiotrophic bacteria can exploit the chemical energy from the oxidation of sulfide or sulfur with oxygen or nitrate for their cell metabolism and growth. At cold seeps, they occur abundantly as chemosynthetic symbionts of bivalves and tube worms (Dubilier et al., 2008), and as free-living bacteria forming conspicuous mats on the seafloor. These microbial mats can show different colors and shapes and mark biogeochemical hotspots at cold seeps, often overlying gas hydrates or accumulations of free gas (Larkin and Henk, 1996; Boetius and Suess, 2004; Joye et al., 2004; Niemann et al., 2006; Omoregie et al., 2008; Grünke et al., 2011).

Many mat-forming sulfide oxidizers of cold seeps belong to the gammaproteobacterial family Beggiatoaceae, including vacuolated, free-living filamentous bacteria like "Candidatus Maribeggiatoa spp." (Ahmad et al., 1999; Teske and Nelson, 2006; nomenclature from Salman et al., 2011), vacuolated, attached filaments like "Candidatus Marithrix spp." (Heijs et al., 2005; Grünke et al., 2011; nomenclature from Salman et al., 2011), and vacuolated, freeliving or attached Thiomargarita spp. (Kalanetra et al., 2005; Bailey et al., 2011; Girnth et al., 2011). Further, the non-vacuolated, aggregate-forming Thiobacterium spp. 
(Gammaproteobacteria; Grünke et al., 2010) and free-living Arcobacter spp. (Epsilonproteobacteria; Omoregie et al., 2008; Grünke et al., 2011) also form dense mats on the seafloor above gassy sediments. Several morphological and physiological traits allow each of these bacteria to adapt to either spatially or temporally varying availabilities of their electron donor (sulfide, elemental sulfur) and acceptor (oxygen or nitrate). In this regard, fluid flow and oxygen or sulfide availability were found to be strong determinants for the distribution of mat-forming sulfide oxidizers at seeps, in caves and other reduced environments (Bernard and Fenchel, 1995; Preisler et al., 2007; Macalady et al., 2008; Grünke et al., 2011 and references therein). In general, the ecological importance of thiotrophic mats lies in the removal of toxic hydrogen sulfide and in the chemosynthetic production of biomass utilized as food source by other organisms (Boetius and Suess, 2004; van Gaever et al., 2006; Lavik et al., 2009; Lichtschlag et al., 2010). The thiotrophs couple the marine carbon and sulfur cycles, but some can also influence the nitrogen and phosphorus cycles, making them important biogeochemical drivers in reduced marine ecosystems (McHatton et al., 1996; Sayama et al., 2005; Schulz and Schulz, 2005; Teske and Nelson, 2006; Lichtschlag et al., 2010; Brock and Schulz-Vogt, 2011).

Here, we studied two types of deep-sea thiotrophic mats of cold seep habitats that occur at the Norwegian continental margin at temperatures permanently close to the freezing point of seawater $\left(-0.7\right.$ to $\left.0.2^{\circ} \mathrm{C}\right)$. The cold seeps investigated include relevant examples of different geological seafloor structures including pockmarks (Nyegga), gas chimneys (Storegga) and a mud volcano (Håkon Mosby mud volcano) (Foucher et al., 2009). One specific aim was to investigate if the macroscopic difference between the mats would be reflected in a different composition of the main mat-forming thiotrophs as well as associated bacteria inhabiting the mats, and if these differences would be explained by biogeochemical variations. Secondly, we aimed at comparing the main types of mat-forming sulfide oxidizers to those previously found at cold seeps of warmer continental margins, or other reduced habitats.

\section{Materials and methods}

\subsection{Sampling}

Samples for this study were recovered from 2006-2010 during four cruises (Supplement Table S1) at three main sites (Fig. 1a). Bacterial mats and underlying sediments were retrieved with ROV-operated push cores (2006, 2007, 2009) or TV-guided multiple corers (2010). In addition, sediment samples outside the Storegga seep area were also recovered with a multiple corer. For each mat sample, replicate corers were obtained in close proximity to link molecular data to geochemical data (Supplement Table S2). The highly gassy sediment samples were incubated close to in situ temperature $\left(0-1{ }^{\circ} \mathrm{C}\right)$ for $1-2$ days before sub-sampling, to allow bacterial mats and geochemical gradients to re-establish. The subsampling of the mats as well as dissection of the sediment for further analyses was performed in the ship's laboratories. All sampling events are summarized in Supplement Table S2. Data have been deposited in PANGAEA (www.pangaea.de).

\subsection{Microscopy}

Bacterial mats were analyzed by bright field and phase contrast microscopy aboard the ship and documented by digital photography. A calibrated eyepiece micrometer or a standardized object micrometer was used for estimating cell dimensions. All mats analyzed microscopically showed the presence of living organisms (e.g. mobile and gliding filaments, ciliates, nematodes); hence, we assume that retrieval under cold polar temperatures helped preserving the original microbial communities despite depressurization during recovery.

\subsection{Clone library construction, sequencing and phylogenetic analyses}

Subsamples of mats were stored at $-20^{\circ} \mathrm{C}$, either without additives or preserved in PCR-grade water (Sigma-Aldrich Biochemie GmbH, Hamburg, Germany) or $1 \times$ TE buffer (Promega Corporation, Madison, WI). Only mat samples taken from the first three positions of a transect along a white mat at the HMMV (ARK-XXII/1b expedition) were directly subjected to replicate polymerase chain reactions (PCR) onboard. Clone library construction and 16S rRNA gene sequencing followed procedures previously published by Girnth et al. (2011) and Grünke et al. (2011) with slight modifications. Details are given as Supplement.

\subsection{Nucleotide sequence accession numbers}

Sequence data have been submitted to the EMBL database under accession No. FR847864-FR847887 (giant sulfur bacteria), No. FR827864 (Menez Gwen filament; see Supplement) and No. FR875365-FR877509 (except FR875905; remaining partial sequences). Part of the Storegga sequence data set has previously been published under accession No. FN597297-FN597418 and No. FN663018-FN663061 (Grünke et al., 2010).

\subsection{Fluorescence in situ hybridization (FISH) experiments}

Sediment samples were fixed in $4 \%$ formaldehyde/seawater, washed twice with $1 \times$ phosphate-buffered saline (PBS; $\mathrm{pH}$ 7.2 to 7.4), and were stored at $-20^{\circ} \mathrm{C}$ in a $1: 1$ mixture of PBS and ethanol until further processing. Catalyzed reporter deposition FISH (CARD-FISH) was carried out with suitable 

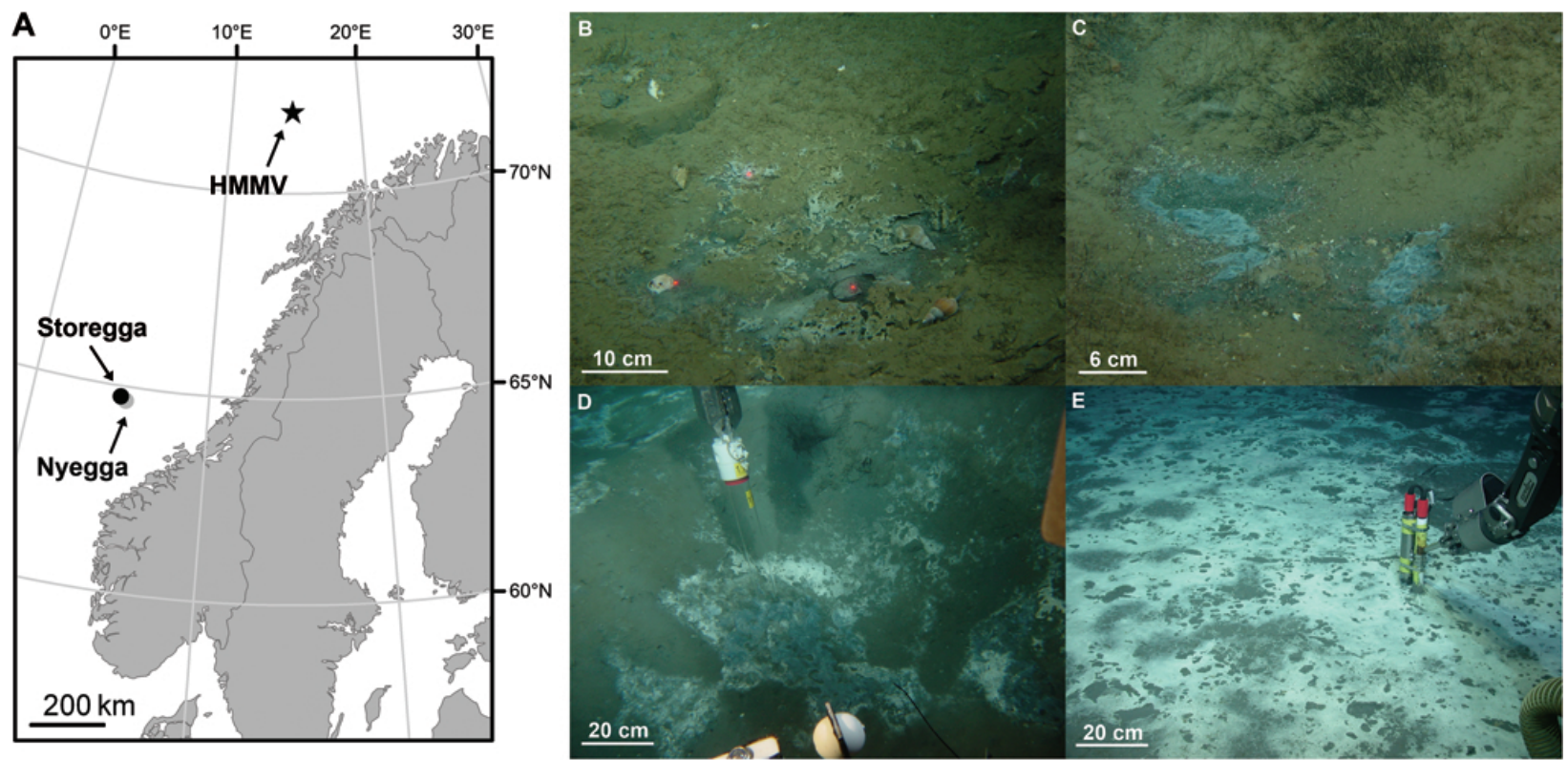

Fig. 1. Thiotrophic mats of the Norwegian margin. (A) Map of the study sites. (B-D) Gray mats at Storegga, Nyegga and the Håkon Mosby mud volcano (HMMV). (Source: Ifremer, Vicking cruise 2006) (E) White mats at the HMMV. (Source: Marum, University Bremen, ARKXXII/1b cruise 2007).

dilutions of the fixed samples as previously described (Pernthaler et al., 2002; Ishii et al., 2004). Horseradish peroxidase (HRP)-labeled probes (Biomers, Ulm, Germany) and hybridization details are given in Supplement Table S3. All cells were counterstained with the DNA-targeting fluorescent stain 4',6-diamidino-2-phenylindole (DAPI). For each sample, a minimum of 30 grids randomly distributed across the filter were counted.

\subsection{Automated ribosomal intergenic spacer analysis (ARISA) and statistics}

To investigate bacterial community patterns associated with the two different types of mats, ARISA was conducted with several samples representing the upper layer of seafloor (maximum depth $2.5 \mathrm{~cm}$ ), thereby following a previously published procedure with slight modifications (Ramette, 2009; for details see Supplement). Three PCR replicates were set up for each sample (except MSM16/2_863-1: only two replicates). Merging of replicate profiles was achieved by considering only operational taxonomic units (OTUs) that occurred at least twice within the three PCR replicates (Ramette, 2009). Non-metric multidimensional scaling (NMDS) plots and analysis of similarity (ANOSIM) were conducted with the PAST software (Version 1.76; Hammer et al., 2001).

\subsection{Microsensor measurements}

High-resolution geochemical gradients in the water column and sediment were measured in situ with a ROV-operated microprofiler unit as described in Treude et al. (2009).
Microsensors for sulfide, $\mathrm{pH}$ and oxygen (Revsbech and Ward, 1983; Jeroschewski et al., 1996; de Beer et al., 1997), as well as a macro temperature sensor (Pt100; UST Umweltsensortechnik $\mathrm{GmbH}$, Geschwenda, Germany), were mounted on the profiler. In addition, ex situ microprofiles were measured in retrieved push cores with a laboratory setup as previously described (Grünke et al., 2010). Microsensor calibration, measurements, profile analyses and calculation of fluxes were performed as previously described by de Beer et al. (2006) and Lichtschlag et al. (2010). The microsensor positioning and data acquisition were performed using custom-made software (Microprofiler 2.9, Lubos Polerecky).

\subsection{Geochemical analyses}

Sulfate reduction (SR) rates were determined ex situ by whole core injection (Jørgensen, 1978). Onboard, incubation with $5-10 \mu \mathrm{l}$ carrier-free ${ }^{35} \mathrm{SO}_{4}^{2-}$ (dissolved in water, $50 \mathrm{kBq}$ ) was carried out in the dark and at in situ temperature for approx. 8-24h. Following incubation, sediment samples were preserved in $20 \mathrm{ml}$ of $20 \%(\mathrm{w} / \mathrm{v}$ ) ZnAc solution. SR rates were measured and calculated as previously described (Kallmeyer et al., 2004; Felden et al., 2010).

Nitrate loss from the overlying water over time was measured in two different cores recovered from Nyegga mats and for one reference site as previously described (Lichtschlag et al., 2010). Background nitrate concentrations were determined in the overlying water as $11 \mu \mathrm{moll}^{-1}$ (PC-11), $7 \mu \mathrm{moll}^{-1}$ (PC-32) and $10 \mu \mathrm{mol}^{-1}$ (MTB2) with the help of 
a chemiluminescence $\mathrm{NO}_{\mathrm{x}}$ analyzer (Thermo Environmental Instruments, Franklin, MA) and based on reduction of $\mathrm{NO}_{2}^{-}$ and $\mathrm{NO}_{3}^{-}$and re-oxidation of the produced $\mathrm{NO}$ by ozone (Braman and Hendrix, 1989). Defined concentrations of nitrate that were approx. 2-5 times higher than the ambient nitrate concentration were added to the overlying water.

\section{Results and discussion}

The microbial mats investigated in this study were associated with three deep-sea cold seep habitats, i.e. Storegga, Nyegga and the Håkon Mosby mud volcano (HMMV), located at water depths between $720-1250 \mathrm{~m}$ at temperatures close to the freezing point of seawater $\left(-0.7\right.$ to $\left.0.2^{\circ} \mathrm{C}\right)$. The Storegga and Nyegga seeps belong to an area at the northern edge of the Storegga Slide, which is characterized by numerous fluid escape structures (Bouriak et al., 2000; Nouzé et al., 2007). Here, subsurface gas chimneys with a positive seafloor expression (Storegga chimneys) and pockmarks with a negative seafloor expression (Nyegga pockmarks G11 and G12; Hovland et al., 2005; Hovland and Svensen, 2006) were investigated. The distance between the two areas was $\sim 15-20 \mathrm{~km}$. Approximately $900 \mathrm{~km}$ northeast of the Storegga Slide, the Håkon Mosby mud volcano is located on the southwest Barents Sea slope and hosts a circular structure of chemosynthetic habitats associated with different levels of fluid flow (e.g. de Beer et al., 2006; Niemann et al., 2006; Felden et al., 2010). A large bacterial mat located in the southeastern part of the HMMV, covering an area of approx. $850 \mathrm{~m}^{2}$, was chosen for extended sampling along a transect (2007).

\subsection{Diversity and distribution of mat-forming thiotrophic bacteria of polar cold seeps}

Samples of two visually different mat types were recovered from the deep Norwegian margin. Smaller gray mat patches of $0.2-5 \mathrm{~m}$ in diameter (Fig. 1b-d) were found in all three investigated areas, with a thickness ranging from few $\mathrm{mm}$ to several $\mathrm{cm}$ above the sediment. In the Storegga and Nyegga area, the $0.2-0.5 \mathrm{~m}$ wide gray mats were often surrounded by thin siboglinid tube worms and other megafauna (Fig. 1b and c). The HMMV gray mats had a larger diameter of $1-5 \mathrm{~m}$ and occurred in the transition zone between high fluid upflow (center) and low fluid upflow (peripheral tube worm fields), but were also found within the low-flow fields in small spots devoid of tube worms (Felden et al., 2010). Some of the gray mat patches were partially overgrown by white mats at their borders (Fig. 1d). Large white mats of $2-100 \mathrm{~m}$ in diameter occurred only at the HMMV (Fig. 1e) and were 1$5 \mathrm{~mm}$ thick. Surrounding the flat active center of the HMMV in a circular zone of $10-50 \mathrm{~m}$ width, they covered up to $11 \%$ of the entire mud volcano structure and were associated with gassy sediments and high fluid upflow (Felden et al., 2010). Upon recovery, microscopic analyses revealed that the macroscopically different mats were dominated by different types of sulfide-oxidizing bacteria.

\subsubsection{Gray mat thiotrophs}

Both macroscopic and microscopic observations revealed a highly variable composition of mat-forming sulfide oxidizers forming gray mat patches (Supplement Table S4): (i) cotton-like, white elemental sulfur filaments that are known to be excreted by Arcobacter spp. of the Epsilonproteobacteria (Sievert et al., 2007; Omoregie et al., 2008) were observed. (ii) Grayish spherical gelatinous mats were formed by Thiobacterium spp., i.e. small rod-shaped bacteria that store grains of elemental sulfur internally (Grünke et al., 2010). Attached to these mats and surrounding sediment were Beggiatoa spp.-like filaments (Fig. 2a), the latter frequently occurring within different gray mat patches (Fig. 2c-e). (iii) Stiff white filaments (Fig. 2b) attached to sediment and tube worms resembled "Candidatus Marithrix spp." (nomenclature from Salman et al., 2011). In addition, we observed (iv) transparent filaments, (v) giant pigmented filaments (Fig. 2f), (vi) Thiomargarita spp.-resembling cells (Fig. 2g) and (vii) dense aggregations of large sulfurcontaining single cells of unknown identity (Fig. 2h). Phylogenetic analyses of gray mat subsamples led to the identification of several 16S rRNA gene sequences as associated with the family of Beggiatoaceae (Fig. 3, Table 1). Closest relatives included "Candidatus Thiomargarita nelsonii" and "Candidatus Thiopilula aggregata" from Namibia (Salman et al., 2011), "Candidatus Marithrix sessilis" species found e.g. at vent-sites (Kalanetra and Nelson, 2010), uncultured bacteria from a sulfidic cave mat (Macalady et al., unpublished) and iron-containing flocculent mat (Hodges and Olson, 2009), as well as Beggiatoa species from a salt marsh (Nelson et al., 1982; Ahmad et al., 2006) and a hypersaline lagoon (de Albuquerque et al., 2010).

\subsubsection{White mat thiotrophs}

Two types of filaments with a morphology characteristic of Beggiatoa spp. (Fig. 2i) dominated the HMMV white mats in all samples analyzed between 2006 and 2010 (Supplement Table S4). Here, we present the first molecular analyses targeting their 16S rRNA genes, which revealed the presence of two distinct phylogenetic groups related to the family Beggiatoaceae. The first phylogenetic group showed close association to sequences of filaments from Tokyo Bay (Kojima and Fukui, 2003; Fig. 3, Table 1). The entire cluster of ten nearly full-length 16S rRNA gene sequences and two partial sequences differ, however, from the type strain ( $88.0 \%$ sequence identity with $B$. alba) and from any other generic cluster of the family $(<93.9 \%)$. Seven sequences of the novel cluster share a sequence identity of $99.0-99.8 \%$ with each other and differ from the other three sequences by $<98.9 \%$. Sequence identities among the latter three 


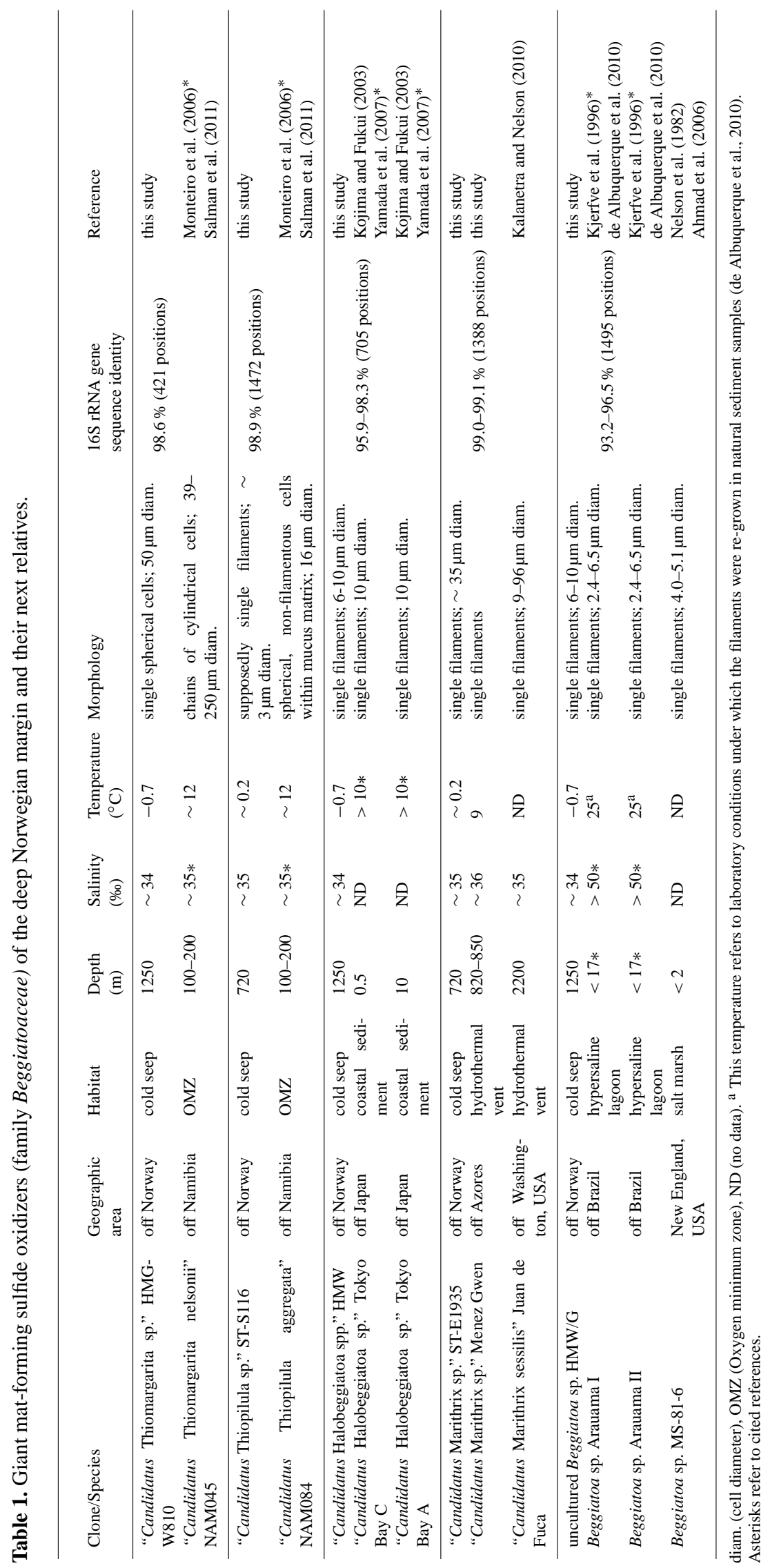



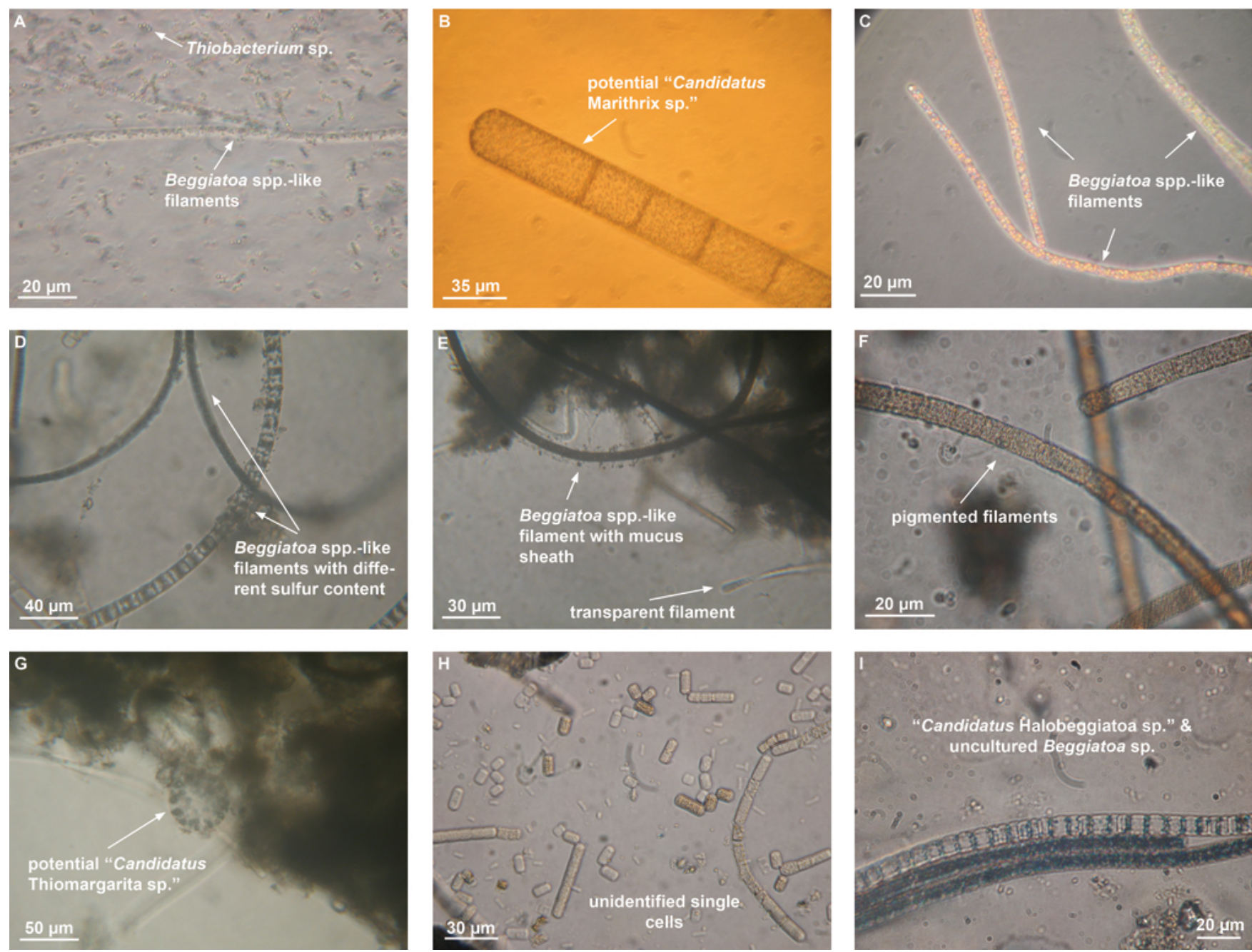

Fig. 2. Mat-forming thiotrophs at deep-sea cold seeps on the Norwegian margin. (A) Filamentous, sulfur-storing bacteria resembling Beggiatoa spp. at Storegga (cell diameter c.d. $\sim 3-4 \mu \mathrm{m}$ ). (B) Filamentous bacteria attached to sediment and tube worms (Storegga), resembling so-called vacuolate-attached filaments, recently classified by Salman et al. (2011) as "Candidatus Marithrix spp." (c.d. $\sim 35 \mu \mathrm{m})$. (C) Sulfurstoring filamentous bacteria at Nyegga resembling Beggiatoa types (c.d. $\sim 3 \mu \mathrm{m})$. (D, E) Different types of filamentous bacteria resembling Beggiatoa in Håkon Mosby mud volcano (HMMV) gray mats (c.d. up to $10 \mu \mathrm{m}$ ). (F) Unidentified, pigmented filaments (HMMV gray mats; c.d. $\sim 7 \mu \mathrm{m}$ ). (G) Single "Candidatus Thiomargarita sp." with a cell diameter of $50 \mu \mathrm{m}$ (HMMV gray mats). (H) Unidentified single cells (HMMV gray mats; c.d. up to $8 \mu \mathrm{m}$ ). (I) Two types of Beggiatoa spp.-like filaments observed within HMMV white mats ("Candidatus Halobeggiatoa spp." and uncultured Beggiatoa spp.; c.d. 6-10 $\mu \mathrm{m})$.

sequences were between 95.6 and $98.1 \%$. For these reasons, we propose a novel Candidatus genus for this monophyletic cluster, which is "Candidatus Halobeggiatoa", along with the Candidatus species "Candidatus Halobeggiatoa borealis" for seven sequences of this cluster sharing $>99.0 \%$ sequence identity (Fig. 3). The other sequences retrieved from this sampling site clustered with a marine (salt marsh) Beggiatoa sp. MS-81-6 (Nelson et al., 1982; Ahmad et al., 2006), as well as with the two Beggiatoa spp. Arauama I and Arauama II from a hypersaline lagoon (de Albuquerque et al., 2010; Fig. 3, Table 1). The two HMMV phylogenetic groups were 87.6-90.6\% identical to each other. Closest relatives occurred at temperatures above $10^{\circ} \mathrm{C}$. In addition to the mat-forming Beggiatoa spp.-like filaments, several transparent filaments were also detected in HMMV white mats. Their phylogenetic identity could not be resolved.

\subsection{Comparison of bacterial communities associated with the different thiotrophic mats}

Mat-forming sulfide oxidizers can act as efficient benthic filters against toxic hydrogen sulfide (Lavik et al., 2009) and may provide high amounts of biomass (Lichtschlag et al., 2010) and exudates as physical substrate or for nutrition (Bernard and Fenchel, 1995; van Dover et al., 2003; van Gaever et al., 2006). Accordingly, they may fit the 


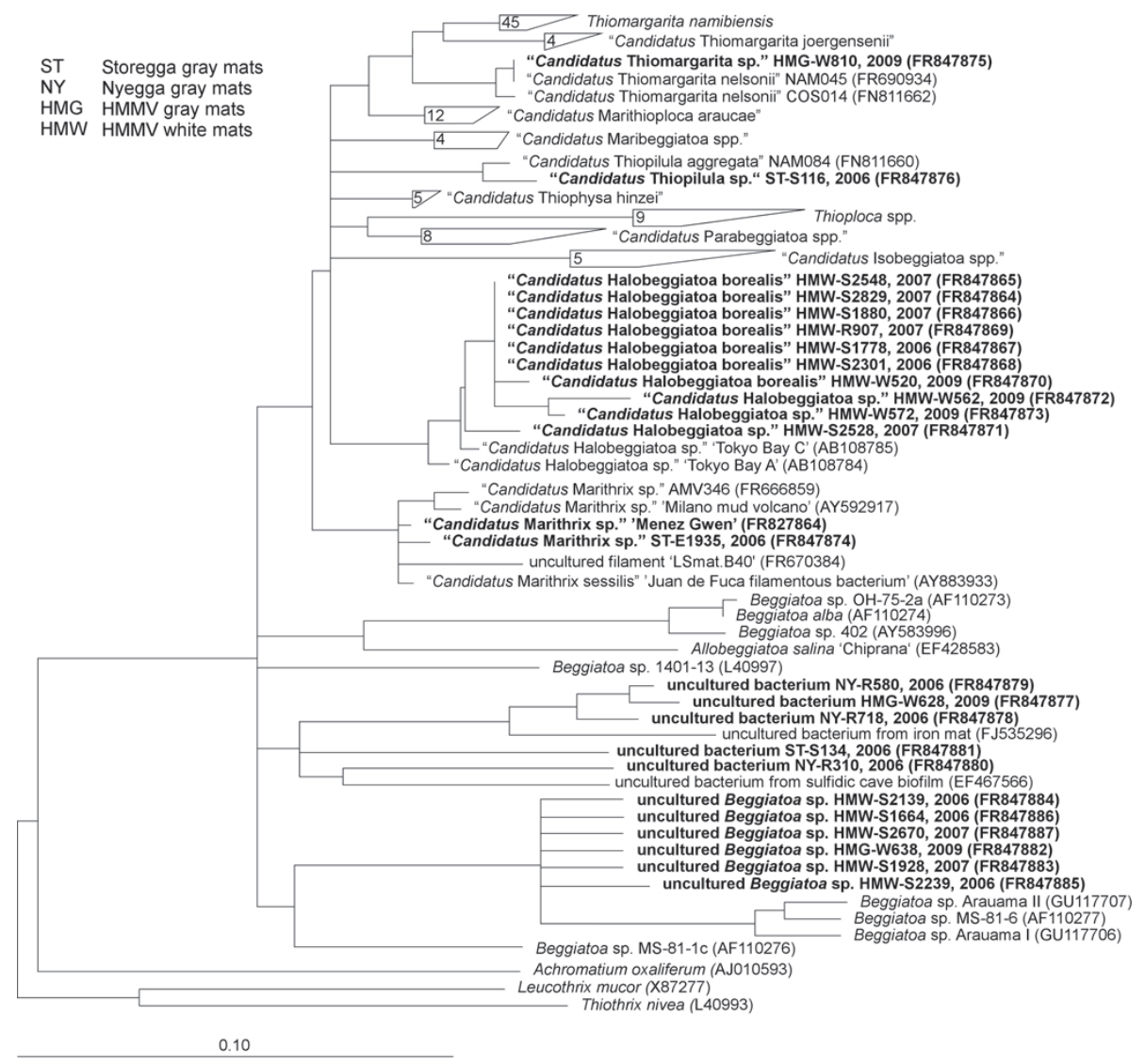

Fig. 3. Phylogenetic tree showing $16 \mathrm{~S}$ rRNA gene sequences obtained within this study (indicated by bold type) that affiliate with the family Beggiatoaceae. Taxonomic nomenclature was adapted from Salman et al. (2011). One new genus, "Candidatus Halobeggiatoa borealis", is proposed based on this study. Tree reconstruction was conducted with 206 nearly full length sequences (Escherichia coli positions 279 to 1463) by applying neighbor joining, maximum likelihood (RAxML) and maximum parsimony methods as well as different conservatory filters. Shorter sequences were added subsequently by applying parsimony criteria. Only selected sequences are shown. Unstable branching orders were visualized by multifurcation. The bar indicates $10 \%$ estimated phylogenetic divergence.

description of Levin and Dayton (2009) as "taxa that provide specialized habitats for unique assemblages of species, creating seafloor biodiversity hotspots" and could be considered as ecosystem engineers, such as corals in a coral reef, or clams in a clam bed. Specific associations between sulfide-oxidizing bacteria and other types of bacteria have been observed before: Sulfate-reducing bacteria of the genus Desulfonema are thought to attach themselves to the mucus sheaths of Thiomargarita (Schulz, 2006) or to inhabit those of Thioploca (Teske et al., 2009), another type of giant matforming thiotroph of the family Beggiatoaceae. Thioploca spp. are also thought to host specific bacterial communities on their sheaths (Kojima et al., 2006), or to form chemosymbiotic relationships with anammox bacteria (Prokopenko et al., 2006).

To compare the bacterial community structure of the two mat types and to investigate a potential role of mat-forming thiotrophs in shaping their associated bacterial diversity, we used whole-cell counting (FISH), conventional clone libraries and the community fingerprinting method ARISA. High proportions of Gamma-, Epsilon-, and Deltaproteobacteria were detected in both gray and white mats (Supplement Table S5), a situation that is typical for the bacterial community composition at sulfidic cold seeps (Mills et al., 2004; Heijs et al., 2005; Omoregie et al., 2008; Omoregie et al., 2009; Grünke et al., 2011; Roalkvam et al., 2011). Different types of methanotrophs (Table 2) and sulfate reducers (see Supplement) were found to be associated with the contact sediments underlying the two mat types, as previously observed (Niemann et al., 2006; Lösekann et al., 2007; Roalkvam et al., 2011).

Community fingerprinting of the bacterial mat communities by ARISA indicated that the total number of OTUs was similar in all mat types, i.e. $130 \pm 20$ OTUs for gray mats (Storegga, Nyegga, HMMV) and $121 \pm 12$ OTUs for white mats (HMMV), and appeared slightly lowered compared to non-mat covered sediments with $166 \pm 18$ OTUs. Gray and white mats shared approx. $60 \%$ of their OTUs. 
Table 2. Summary of geochemical parameters characterizing thiotrophic mats in the Storegga and Nyegga area and at the Håkon Mosby mud volcano.

\begin{tabular}{|c|c|c|c|c|c|c|}
\hline \multirow{3}{*}{ Sampling site } & \multicolumn{5}{|c|}{ Measurement/Analysis } & \multirow{3}{*}{ Reference } \\
\hline & \multicolumn{2}{|c|}{ Microprofiles $^{\mathrm{a}}$} & \multirow{2}{*}{$\begin{array}{l}\text { Nitrate uptake } \\
\left(\mathrm{mmol} \mathrm{m} \mathrm{m}^{-2} \mathrm{~d}^{-1}\right)\end{array}$} & \multirow{2}{*}{$\begin{array}{l}\mathrm{SR}^{\mathrm{b}} \\
\left(\mathrm{mmol} \mathrm{m}{ }^{-2} \mathrm{~d}^{-1}\right)\end{array}$} & \multirow{2}{*}{$\begin{array}{l}\text { Dominating } \\
\text { ANME } \\
\text { population }^{\mathrm{c}}\end{array}$} & \\
\hline & $\begin{array}{l}\text { DOU } \\
\left(\mathrm{mmol} \mathrm{m}^{-2} \mathrm{~d}^{-1}\right)\end{array}$ & $\begin{array}{l}\text { Sulfide flux } \\
\left(\mathrm{mmol} \mathrm{m} \mathrm{m}^{-2} \mathrm{~d}^{-1}\right)\end{array}$ & & & & \\
\hline Storegga gray mats & $\begin{array}{l}4.2-35.2 \\
\text { (average: } 15.6 \text { ) }\end{array}$ & $\begin{array}{l}5.0-10.1 \\
\text { (average: 7.6) }\end{array}$ & & $\begin{array}{l}0.3-70.7 \\
\text { (average: } 23.2 \text { ) }\end{array}$ & ANME1 & this study \\
\hline Nyegga gray mats & $\begin{array}{l}\text { 13.8-17.8 } \\
\text { (average: } 15.8 \text { ) }\end{array}$ & $\begin{array}{l}4.2-12.3 \\
\text { (average: } 8.2 \text { ) }\end{array}$ & $\begin{array}{l}4.4-7.3 \\
\text { (average: 5.9) }\end{array}$ & $\begin{array}{l}25.3-201.9 \\
\text { (average: } 113.6 \text { ) }\end{array}$ & $\begin{array}{l}\text { ANME1 } \\
\text { ANME2 }\end{array}$ & this study \\
\hline Reference Storegga/Nyegga & $2.0( \pm 0.1)$ & 0 & 0.2 & 0 & $0 *$ & this study \\
\hline HMMV gray mats & $\begin{array}{l}34.7-59.4 \\
(\text { average: } 45.2)^{2}\end{array}$ & $\begin{array}{l}17-131^{2} \\
\text { (average: 74) }\end{array}$ & $4.5^{2}$ & $\begin{array}{l}9.5-108.3^{1,2} \\
\text { (average: } 48.4 \text { ) }\end{array}$ & $\begin{array}{l}\text { ANME }^{3} \\
\text { ANME3 }^{3}\end{array}$ & $\begin{array}{l}\text { Felden et al. }(2010)^{1} \text {, } \\
\text { Lichtschlag et al. }(2010)^{2} \text {, } \\
\text { this study }{ }^{3}\end{array}$ \\
\hline Next to HMMV gray mats & $\begin{array}{l}20.7-45.6 \\
\text { (average: } 35.2 \text { ) }\end{array}$ & 4.8 & & & & Lichtschlag et al. (2010) \\
\hline HMMV white mats & $\begin{array}{l}23.6-38.8 \\
(\text { average: } 33.7)^{2}\end{array}$ & $11.6^{2}$ & $1.5-102^{2}$ & $\begin{array}{l}2.8-28.7^{1,2} \\
\text { (average: } 11.8 \text { ) }\end{array}$ & $\begin{array}{l}\text { ANME1 }^{3} \\
\text { ANME3 }^{3}\end{array}$ & $\begin{array}{l}\text { Felden et al. }(2010)^{1} \text {, } \\
\text { Lichtschlag et al. }(2010)^{2} \text {, } \\
\text { this study }{ }^{3}\end{array}$ \\
\hline Next to HMMV white mats & $\begin{array}{l}8.6-9.9 \\
\text { (average: } 9.2 \text { ) }\end{array}$ & 7 & & & & Lichtschlag et al. (2010) \\
\hline
\end{tabular}

DOU (Diffusive oxygen uptake), SR (Sulfate reduction), ANME (ANaerobic MEthanotrophs), HMMV (Håkon Mosby mud volcano). Superscript numbers refer to cited references. $0 *$ (Station was oxic up to $10 \mathrm{~cm}$ below the surface; therefore, ANME abundances were not determined.) For additional information, see Supplement. ${ }^{\text {a }}$ Refers to in situ determined fluxes, except Storegga mats (ex situ). ${ }^{\mathrm{b}}$ Integrated SR rates were determined ex situ for the upper $10 \mathrm{~cm}$ of sediment. ${ }^{\mathrm{c}}$ Determined with Catalyzed reporter deposition fluorescence in situ hybridization (CARD-FISH).

However, when comparing bacterial community structures by NMDS (Fig. 4), a clear separation of gray and white mat bacterial community composition could be observed and was statistically confirmed by significant ANOSIM ( $p<0.001$, Bonferroni-corrected). The percentage of shared OTUs between the thiotroph-harboring communities and the non-seep sediment community was only $41 \%$, and the percentage of overlap with non-mat covered seep sediment communities was only $63 \%$, indicating that the gray and white mats host structurally distinct bacterial communities. The specific association of distinct bacterial communities with the white or gray mats may be due to biological factors like specific interactions with the mat-forming thiotrophs, biogeochemical factors like sulfide flux, and/or selective grazing by the highly abundant nematodes in the mats (van Gaever et al., 2006). In the following, we focused on the effects of biogeochemical factors shaping the thiotrophic community composition in the different mat types.

\subsection{Biogeochemical processes in gray and white mats}

The ecological niches of mat-forming sulfide oxidizers are influenced by the presence and fluxes of their electron donor (sulfide) and acceptor (oxygen, nitrate), the spatial and temporal dynamics of energy availability (Macalady et al., 2008; Girnth et al., 2011; Grünke et al., 2011), and physical conditions (Macalady et al., 2008). When comparing the biogeochemical characteristics of gray and white mat habitats of the Norwegian margin, we found clear differences between the mats and a non-seep reference site, as well as between mat sites and seep habitats not covered by sulfide oxidizers (Table 2). The high sulfide fluxes certainly explain why sulfide oxidizers are specifically enriched at the investigated cold seep sites compared to the otherwise relatively oligotrophic conditions of the deep Norwegian margin. They may also represent the main cause for substantial differences in bacterial community structure between the reference sites and mats (Fig. 4). However, comparing sulfide and total oxygen fluxes between the different mat habitats, no major differences were detected (Table 2). A clear distinction between white and gray mats was only identified in the vertical positions of oxygen and sulfide gradients (Fig. 5). Accordingly, the bacterial OTUs associated with thiotrophic mats showed a considerable overlap ( $60 \%$ shared OTUs) as compared to non-seep reference sediment (41\% shared OTUs), but also differences in bacterial community structures between the high flux HMMV gray mats, the low flux Storegga and Nyegga gray mats and the white mats (Fig. 4).

In situ microprofiling of Nyegga gray mats revealed an overlap of oxygen and sulfide and their consumption within the $1-50 \mathrm{~mm}$ thick mats (Fig. 5a). Oxygen consumption rates were 7-9 times higher than in reference sediment, where sulfide was absent (Fig. 5b). Overlapping oxygen-sulfide gradients have already been previously reported for the HMMV gray mats (de Beer et al., 2006; Lichtschlag et al., 2010; Fig. 5c), including complete and incomplete aerobic oxidation of sulfide as well as the use of nitrate as alternative 


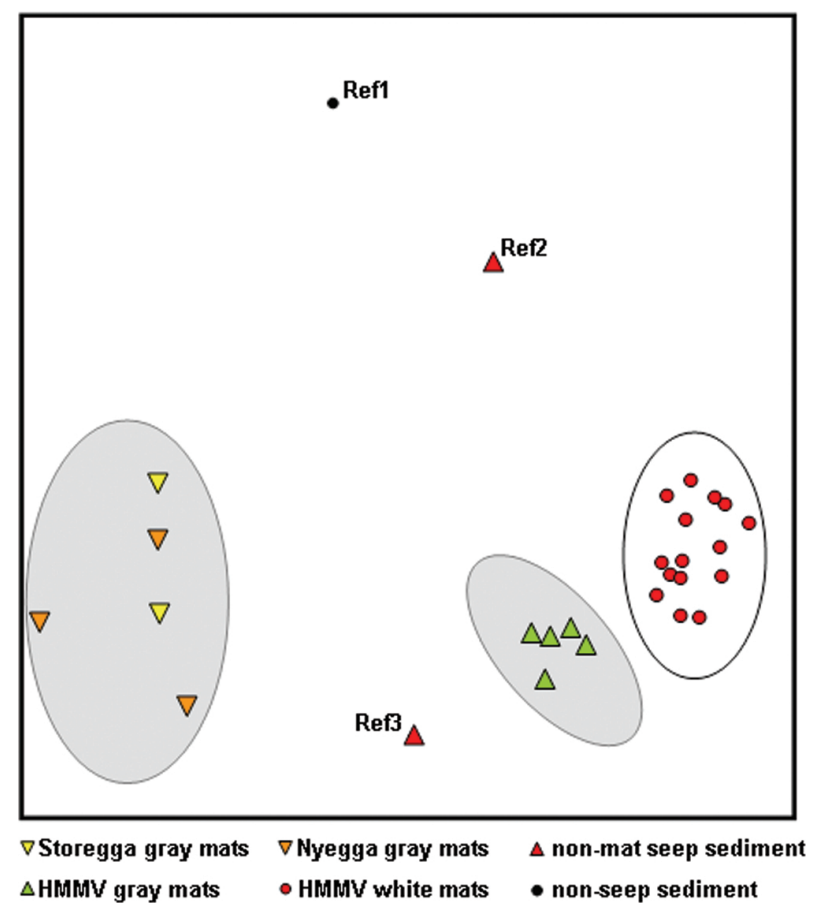

Fig. 4. NMDS plot (based on a Bray-Curtis distance matrix) of ARISA-derived bacterial community profiles of the Storegga, Nyegga and Håkon Mosby mud volcano (HMMV) gray mats as well as HMMV white mats. The stress value of the ordination was 0.095, indicating a good representation of the original matrix into the reduced space. Non-seep associated sediment (Ref1) was obtained in the vicinity of the Storegga/Nyegga area with a multiple corer (2006). Non-mat covered seep references were obtained with push cores at the HMMV: Ref2 was recovered from the periphery (tube worm field) of the mud volcano (2009), while Ref3 was taken approx. $10 \mathrm{~m}$ away from a white mat (2007).

electron acceptor (Lichtschlag et al., 2010; Table 2). Furthermore, the gray mats have mostly been observed in transition zones influenced by fluctuations in gas and mud flow (de Beer et al., 2006; Felden et al., 2010). The small and highly motile Arcobacter spp. as well as the large and oxygendepletion tolerant Thiomargarita spp. were found within the gray mats, and both types of sulfide oxidizers are thought to be pioneer colonizers of dynamic habitats (Schulz, 2006; Sievert et al., 2007; Girnth et al., 2011). Marine mat-forming Arcobacter spp. can tolerate sulfide concentrations of at least $1-2 \mathrm{~mm}$ and are thought to proliferate well in dynamic environments based on their motile behavior and the potential use of excreted elemental sulfur filaments for maintaining a favorable position in changing oxygen-sulfide gradients (Sievert et al., 2007; Omoregie et al., 2008). As microaerophilic bacteria, marine mat-forming Arcobacter spp. need the presence of oxygen $(1-10 \mu \mathrm{M}$; Sievert et al., 2007). In contrast, the giant sulfur bacterium Thiomargarita can survive periods of anoxia by using internally accumulated nitrate $(100-800 \mathrm{mM})$ as alternative electron acceptor for sulfide
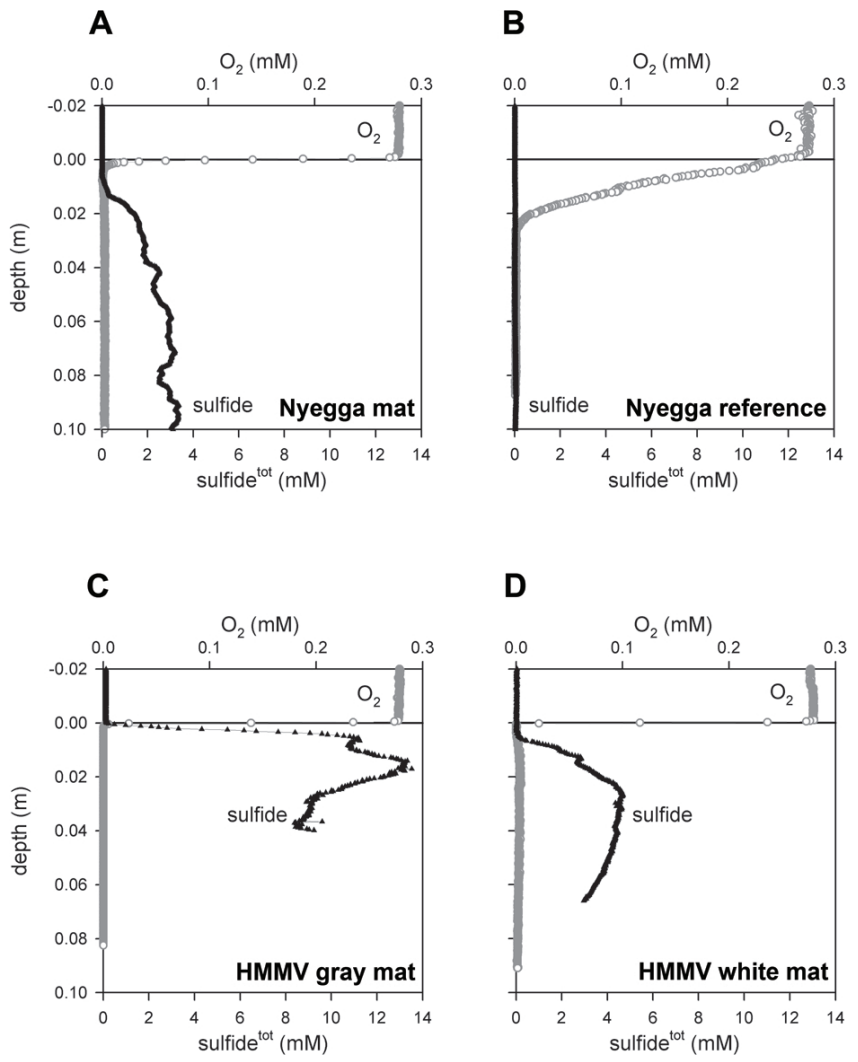

Fig. 5. High-resolution in situ microprofiles of oxygen $\left(\mathrm{O}_{2}\right)$ and sulfide ( sulfide ${ }^{\text {tot }}=\mathrm{H}_{2} \mathrm{~S}+\mathrm{HS}^{-}+\mathrm{S}^{2-}$ ) recorded (A) on a Nyegga gray mat in the vicinity of pockmark $\mathrm{G} 12$, (B) on reference sediment between pockmark G11 and G12, (C) on a Håkon Mosby mud volcano (HMMV) gray mat, and (D) on a HMMV white mat (C and D modified from Lichtschlag et al., 2010). Oxygen and sulfide fluxes corresponding to the different profiles are listed in Table 2.

oxidation (Schulz et al., 1999; Kalanetra et al., 2005; Schulz, 2006). Also, Thiomargarita spp. are tolerant of high concentrations of sulfide (up to $19 \mathrm{mM}$; Schulz et al., 1999; Kalanetra et al., 2005; Schulz, 2006; Girnth et al., 2011). As non-motile organisms, they seem to rely on external mixing events to get into contact with their electron donor and acceptor (Schulz, 2006; Girnth et al., 2011).

A comparison of the distributions of white mats at the HMMV between 2001 and 2009 showed that most of them remained stable in space and time (de Beer et al., 2006; Niemann et al., 2006; Felden et al., 2010; Lichtschlag et al., 2010; this study). The integrated SR rates under the HMMV white mats were less variable than the rates measured in gray mats (Table 2, Supplement Table S6). The spatial separation of oxygen and sulfide by approx. $4 \mathrm{~mm}$ (Fig. 5d; Lichtschlag et al., 2010) appears to hold the main clue to the dominance of Beggiatoa species. Vacuolated, nitrate-storing Beggiatoa spp. can bridge gaps between their preferred electron donor (sulfide) and acceptor (oxygen) by means of their gliding motility and the use of stored elemental sulfur and nitrate 
Table 3. Psychrophilic behavior of polar mat-forming thiotrophs.

\begin{tabular}{|c|c|c|c|c|c|}
\hline $\begin{array}{l}\text { Target area/ } \\
\text { Mat type }\end{array}$ & $\begin{array}{l}\text { Analyzed push core } \\
\text { (year) }\end{array}$ & Mat-dominating bacteria & $\begin{array}{l}T_{\text {bottom }} \\
\left({ }^{\circ} \mathrm{C}\right)\end{array}$ & $\begin{array}{l}T_{\text {viable }} \\
\left({ }^{\circ} \mathrm{C}\right)\end{array}$ & $\begin{array}{l}T_{\text {dead }} \\
\left({ }^{\circ} \mathrm{C}\right)\end{array}$ \\
\hline \multirow[t]{3}{*}{$\begin{array}{l}\text { Storegga } \\
\text { gray mats }\end{array}$} & $\begin{array}{l}\text { VKGD275/PC-1 } \\
(2006)\end{array}$ & $\begin{array}{l}\text { Arcobacter mats } \\
\text { sulfur-storing Beggiatoa spp.-like filaments }\end{array}$ & $\sim 0.2$ & $\sim 0$ & $>8$ \\
\hline & $\begin{array}{l}\text { VKGD275/PC-2 } \\
(2006)\end{array}$ & $\begin{array}{l}\text { Thiobacterium mats and cells } \\
\text { sulfur-storing Beggiatoa spp.-like filaments associated with } \\
\text { Thiobacterium mats and sediment }\end{array}$ & $\sim 0.2$ & $\sim 0$ & $>8$ \\
\hline & $\begin{array}{l}\text { VKGD275/PC-11 } \\
(2006)\end{array}$ & $\begin{array}{l}\text { sulfur-storing filaments attached to worms and sediment re- } \\
\text { sembling "Candidatus Marithrix spp." }\end{array}$ & $\sim 0.2$ & $\sim 0$ & $>8$ \\
\hline \multirow[t]{2}{*}{$\begin{array}{l}\text { Nyegga } \\
\text { gray mats }\end{array}$} & $\begin{array}{l}\text { VKGD272/PC-11 } \\
(2006)\end{array}$ & sulfur-storing filaments attached to worms & $\sim 0.2$ & $\sim 0$ & $>8$ \\
\hline & $\begin{array}{l}\text { VKGD272/PC-32 } \\
(2006)\end{array}$ & sulfur-storing Beggiatoa spp.-like filaments & $\sim 0.2$ & $\sim 0$ & $>8$ \\
\hline $\begin{array}{l}\text { HMMV } \\
\text { gray mats }\end{array}$ & $\begin{array}{l}\text { VKGD277/PC-8 } \\
\text { (2006) }\end{array}$ & $\begin{array}{l}\text { unknown single cells (some pigmented) } \\
\text { sulfur-storing Beggiatoa spp.-like filaments }\end{array}$ & -0.7 & $\sim 0$ & $>8$ \\
\hline \multirow[t]{4}{*}{$\begin{array}{l}\text { HMMV } \\
\text { white mats }\end{array}$} & $\begin{array}{l}\text { VKGD276/PC-1 } \\
(2006)\end{array}$ & 1-2 types of sulfur-storing Beggiatoa spp.-like filaments & -0.7 & $\sim 0$ & $>8$ \\
\hline & $\begin{array}{l}\text { VKGD276/PC-2 } \\
(2006)\end{array}$ & 1-2 types of sulfur-storing Beggiatoa spp.-like filaments & -0.7 & $\sim 0$ & $>8$ \\
\hline & $\begin{array}{l}\text { VKGD276/PC-3 } \\
\text { (2006) }\end{array}$ & 1-2 types of sulfur-storing Beggiatoa spp.-like filaments & -0.7 & $\sim 0$ & $>8$ \\
\hline & $\begin{array}{l}\text { MSM16/2_863-1 } \\
(2010)\end{array}$ & 1-2 types of sulfur-storing Beggiatoa spp.-like filaments & -0.7 & $\sim 0$ & $>4$ \\
\hline
\end{tabular}

$T_{\text {bottom }}$ (bottom water temperature), $T_{\text {viable }}$ (assessed by observations of an intact mat structure and, in the case of filamentous bacteria, an intact filament structure and motility), $T_{\text {dead }}$ (temperature at which mats and cells disintegrated).

for metabolic activity (McHatton et al., 1996; Sayama et al., 2005). The nitrate content of the HMMV filaments was $110 \mathrm{mmol}^{-1}$ (Lichtschlag et al., 2010). Under stable conditions, and by pushing the sulfide front deeper into the sediment and away from oxygen (Nelson et al., 1986), Beggiatoa spp. may eventually outcompete other thiotrophs in this habitat. However, Beggiatoa are known to feature phobic responses against high concentrations of sulfide $(>1 \mu \mathrm{M}$; Preisler et al., 2007) and oxygen (Møller et al., 1985), and were found to orient themselves in defined oxygen-sulfide gradients (Nelson et al., 1986; Preisler et al., 2007; Girnth et al., 2011). This may cause disadvantages in the gray mat habitat, and could explain why Beggiatoa filaments were never able to dominate these dynamic habitats.

\subsection{Indications for psychrophilic nature of polar thiotrophs}

The direct and indirect effects of temperature on speciation and community composition are already known from several types of bacteria (e.g. Urakawa et al., 2008; Adams et al., 2010), protists (e.g. Darling et al., 2004), and plants (e.g. Jansson and Davies, 2008; Wang et al., 2009). The temperature ranges of mat-forming thiotrophs, though, have not been systematically documented yet. Beggiatoa spp. may survive temporary freezing of seawater (Dunker et al., 2010) and can be widely distributed within Arctic fjord sediments at temperatures close to $0^{\circ} \mathrm{C}$ (Jørgensen et al., 2010).

The cold seeps of the deep Norwegian margin represent one of the coldest habitats $\left(-0.7\right.$ to $\left.0.2^{\circ} \mathrm{C}\right)$ from which the development of thick mats of thiotrophs has been reported (Nelson et al., 1989; McHatton et al., 1996; Glud et al., 2004; Hovland et al., 2005; Jørgensen et al., 2010; Lichtschlag et al., 2010; Pedersen et al., 2010; Lanzén et al., 2011). By repeated observations of recovered gray and white mat samples, we found clear evidence for psychrophily of the dominating thiotrophs (Table 3 ). The gray mats remained intact approx. one week at $\sim 0{ }^{\circ} \mathrm{C}$ in the ship's laboratory, but dissolved immediately when exposed to higher temperatures, i.e. from -1 to $0^{\circ} \mathrm{C}$ incubations to $8^{\circ} \mathrm{C}$ in the refrigerated lab. The white mats could be kept alive for $>8$ weeks at temperatures around $0^{\circ} \mathrm{C}$ as indicated by an intact mat structure and the presence of viable, gliding Beggiatoa filaments. However, after transferring subsamples or whole intact cores to $>4$ or $8^{\circ} \mathrm{C}$, the mats rapidly disintegrated within one day. Even cultivation experiments in gradient media that were started with viable Beggiatoa filaments showed an unusually fast and unexpected disintegration of the thiotrophs at $4{ }^{\circ} \mathrm{C}$ (media as in Schwedt et al., 2012). Although these observations might not constitute final proof for the psychrophily of polar mat-forming sulfide oxidizers, we believe 
our observations to present a remarkable finding of a highly narrow temperature range that may be an important ecological and/or biological cue for these polar thiotrophs.

None of the sequences obtained in this study were related to the known Arctic Beggiatoaceae, i.e. "Candidatus Isobeggiatoa sp.", from shallow-water Svalbard fjords (Jørgensen et al., 2010; nomenclature from Salman et al., 2011; sequence identities 85.1-90.8\%) that have been found at $214 \mathrm{~m}$ water depth in Smeerenburgfjorden at a temperature of $0.4{ }^{\circ} \mathrm{C}$ (Jørgensen et al., 2010) and 32\%o salinity (Arnosti, 2003). Instead, most of the giant mat-forming sulfide oxidizers found here, thriving at temperatures close to the freezing point, were highly related to, but still phylogenetically and morphologically different from, types previously found in temperate or warm aquatic ecosystems (Fig. 3, Table 1). Overall, our observations suggest that temperature may be an important factor in the diversification of mat-forming sulfur bacteria of the deep sea, and that polar microorganisms could be highly sensitive to warming of the environment by a few degrees.

\section{Summary}

Gray and white thiotrophic mats associated with gas chimneys in the Storegga area, complex pockmarks in the Nyegga area and the Håkon Mosby mud volcano were compared regarding geochemical gradients and the mat-associated bacterial communities. Associated with rather dynamic conditions regarding gas and fluid flow, the gray mats potentially provide a great variety of microenvironments and ecological niches. Overlapping gradients of sulfide and oxygen allowed diverse members of the family Beggiatoaceae as well as of the genus Arcobacter to settle and use the energy provided by high sulfide fluxes from anaerobic oxidation of methane. In contrast, the stable spatial separation of oxygen and sulfide in the white mats appeared to select for only two types of Beggiatoa species. Only these giant thiotrophs can bridge this gap by their gliding motility and the ability to accumulate large amounts of both electron donor (sulfur) and acceptor (nitrate).

Most of the identified giant sulfide oxidizers were closely related to known members of the Beggiatoaceae populating temperate and warm oceans. Yet, differences to known types were found at the level of their 16S rRNA gene sequences (1-7\%) and in their cell morphology, indicating that adaptation to temperature may be an important factor in generating diversity for these thiotrophs. Furthermore, whole-cell hybridization and high-throughput fingerprinting revealed that distinct bacterial communities were associated with the two mat types. These results suggest an important ecological impact of thiotrophic mats on overall bacterial diversity in the deep sea.

\section{Supplementary material related to this article is available online at: http://www.biogeosciences.net/9/ 2947/2012/bg-9-2947-2012-supplement.pdf.}

Acknowledgements. We thank the chief scientists and crews of R/V Pourquoi Pas? and ROV Victor 6000 (Ifremer, France), R/V Polarstern and ROV Quest 4000 (Marum, University of Bremen), and R/V Maria S. Merian. We further thank Frank Wenzhöfer and the Habitat Group sea technicians Jörn P. Meyer, Axel Nordhausen, Volker Asendorf and Marc Viehweger for their great support with work at sea. We thank Hans Røy (Center of Geomicrobiology, University of Aarhus, Denmark), Marc Mußmann and Anne-Christin Girnth for helpful discussions on the manuscript, and Erika Weiz, Wiebke Rentzsch, Rafael Stiens, Tomas Wilkop, Gabriele Schüssler and the Microsensor Group technicians for technical support.

The research leading to these results has received funding from the European Community's Sixth Framework Programme under the HERMES project (GOCE-CT-2005-511234-1), the Seventh Framework Programme (FP7/2007-2013) under the HERMIONE project (grant agreement no. 226354), as well as from the Helmholtz Association and the Max Planck Society. It was inspired by the Census of Marine Life program CHESS "Biogeography, Ecology and Vulnerability of Chemosynthetic Ecosystems in the Deep Sea".

The service charges for this open access publication have been covered by the Max Planck Society.

Edited by: R. Santos

\section{References}

Adams, H. E., Crump, B. C., and Kling, G. W.: Temperature controls on aquatic bacterial production and community dynamics in arctic lakes and streams, Environ. Microbiol., 12, 1319-1333, 2010.

Ahmad, A., Barry, J. P., and Nelson, D. C.: Phylogenetic affinity of a wide, vacuolate, nitrate-accumulating Beggiatoa sp. from Monterey Canyon, California, with Thioploca spp., Appl. Environ. Microbiol., 65, 270-277, 1999.

Ahmad, A., Kalanetra, K. M., and Nelson, D. C.: Cultivated Beggiatoa spp. define the phylogenetic root of morphologically diverse, noncultured, vacuolate sulfur bacteria, Can. J. Microbiol., 52, 591-598, 2006.

Arnosti, C.: Fluorescent derivatization of polysaccharides and carbohydrate-containing biopolymers for measurement of enzyme activities in complex media, J. Chromatogr. B, 793, 181191, 2003.

Bailey, J. V., Salman, V., Rouse, G., Schulz-Vogt, H. N., Levin, L., and Orphan, V.: Dimorphism in methane seep-dwelling ecotypes of the largest known bacteria, ISME J., 5, 1926-1935, 2011.

Bernard, C. and Fenchel, T.: Mats of colourless sulphur bacteria, II. Structure, composition of biota and successional patterns, Mar. Ecol. Prog. Ser., 128, 171-179, 1995.

Boetius, A. and Suess, E.: Hydrate Ridge: a natural laboratory for the study of microbial life fueled by methane from near-surface gas hydrates, Chem. Geol., 205, 291-310, 2004. 
Boetius, A., Ravenschlag, K., Schubert, C. J., Rickert, D., Widdel, F., Gieseke, A., Amann, R., Jørgensen, B. B., Witte, U., and Pfannkuche, O.: A marine microbial consortium apparently mediating anaerobic oxidation of methane, Nature, 407, 623-626, 2000.

Bouriak, S., Vanneste, M., and Saoutkine, A.: Inferred gas hydrates and clay diapirs near the Storegga Slide on the southern edge of the Vøring Plateau, offshore Norway, Mar. Geol., 163, 125-148, 2000.

Braman, R. S. and Hendrix, S. A.: Nanogram nitrite and nitrate determination in environmental and biological materials by vanadium(III) reduction with chemiluminescence detection, Anal. Chem., 61, 2715-2718, 1989.

Brock, J. and Schulz-Vogt, H. N.: Sulfide induces phosphate release from polyphosphate in cultures of a marine Beggiatoa strain, ISME J., 5, 497-506, 2011.

Cathles, L. M., Su, Z., and Chen, D.: The physics of gas chimney and pockmark formation, with implications for assessment of seafloor hazards and gas sequestration, Mar. Petrol. Geol., 27, 82-91, 2010.

Darling, K. F., Kucera, M., Pudsey, C. J., and Wade, C. M.: Molecular evidence links cryptic diversification in polar planktonic protists to Quaternary climate dynamics, Proc. Natl. Acad. Sci. USA, 101, 7657-7662, 2004.

de Albuquerque, J. P., Neumann Keim, C., and Lins, U.: Comparative analysis of Beggiatoa from hypersaline and marine environments, Micron, 41, 507-517, 2010.

de Beer, D., Schramm, A., Santegoeds, C. M., and Kühl, M.: A nitrite microsensor for profiling environmental biofilms, Appl. Environ. Microbiol., 63, 973-977, 1997.

de Beer, D., Sauter, E., Niemann, H., Kaul, N., Foucher, J.-P., Witte, U., Schlüter, M., and Boetius, A.: In situ fluxes and zonation of microbial activity in surface sediments of the Håkon Mosby Mud Volcano, Limnol. Oceanogr., 51, 1315-1331, 2006.

Dimitrov, L. I.: Mud volcanoes - the most important pathway for degassing deeply buried sediments, Earth-Sci. Rev., 59, 49-76, 2002.

Dubilier, N., Bergin, C., and Lott, C.: Symbiotic diversity in marine animals: the art of harnessing chemosynthesis, Nat. Rev. Microbiol., 6, 725-740, 2008.

Dunker, R., Røy, H., and Jørgensen, B. B.: Temperature regulation of gliding motility in filamentous sulfur bacteria, Beggiatoa spp., FEMS Microbiol. Ecol., 73, 234-242, 2010.

Felden, J., Wenzhöfer, F., Feseker, T., and Boetius, A.: Transport and consumption of oxygen and methane in different habitats of the Håkon Mosby Mud Volcano (HMMV), Limnol. Oceanogr., 55, 2366-2380, 2010.

Foucher, J. P., Westbrook, G. K., Boetius, A., Ceramicola, S., Dupre, S., Mascle, J., Mienert, J., Pfannkuche, O., Pierre, C., and Praeg, D.: Structure and Drivers of Cold Seep Ecosystems, Oceanography, 22, 92-109, 2009.

Girnth, A.-C., Grünke, S., Lichtschlag, A., Felden, J., Knittel, K., Wenzhöfer, F., de Beer, D., and Boetius, A.: A novel, matforming Thiomargarita population associated with a sulfidic fluid flow from a deep-sea mud volcano Environ. Microbiol., 13, 495-505, 2011.

Glud, R. N., Rysgaard, S., Fenchel, T., and Nielsen, P. H.: A conspicuous $\mathrm{H}_{2} \mathrm{~S}$-oxidizing microbial mat from a high-latitude Arctic fjord (Young Sound, NE Greenland), Mar. Biol., 145, 51-60,
2004.

Grünke, S., Lichtschlag, A., de Beer, D., Kuypers, M., LösekannBehrens, T., Ramette, A., and Boetius, A.: Novel observations of Thiobacterium, a sulfur-storing Gammaproteobacterium producing gelatinous mats, ISME J., 4, 1031-1043, 2010.

Grünke, S., Felden, J., Lichtschlag, A., Girnth, A.-C., de Beer, D., Wenzhöfer, F., and Boetius, A.: Niche differentiation among matforming, sulfide-oxidizing bacteria at cold seeps of the Nile Deep Sea Fan (Eastern Mediterranean Sea), Geobiology, 9, 330-348, 2011.

Hammer, Ø., Harper, D. A. T., and Ryan, P. D.: PAST: Paleontological statistics software package for education and data analysis, Palaeontol. Electron., 4, available at: http://palaeo-electronica. org/2001_2001/past/issue2001_2001.htm, 2001.

Heijs, S. K., Sinninghe Damsté, J. S., and Forney, L. J.: Characterization of a deep-sea microbial mat from an active cold seep at the Milano mud volcano in the Eastern Mediterranean Sea, FEMS Microbiol. Ecol., 54, 47-56, 2005.

Hodges, T. W. and Olson, J. B.: Molecular comparison of bacterial communities within iron-containing flocculent mats associated with submarine volcanoes along the Kermadec Arc, Appl. Environ. Microbiol., 75, 1650-1657, 2009.

Hovland, M. and Svensen, H.: Submarine pingoes: Indicators of shallow gas hydrates in a pockmark at Nyegga, Norwegian Sea, Mar. Geol., 228, 15-23, 2006.

Hovland, M., Svensen, H., Forsberg, C. F., Johansen, H., Fichler, C., Fosså, J. H., Jonsson, R., and Rueslåtten, H.: Complex pockmarks with carbonate-ridges off mid-Norway: Products of sediment degassing, Mar. Geol., 218, 191-206, 2005.

Ishii, K., Mussmann, M., MacGregor, B. J., and Amann, R.: An improved fluorescence in situ hybridization protocol for the identification of bacteria and archaea in marine sediments, FEMS Microbiol. Ecol., 50, 203-213, 2004.

Jansson, R. and Davies, T. J.: Global variation in diversification rates of flowering plants: energy vs. climate change, Ecol. Lett., 11, 173-183, 2008.

Jeroschewski, P., Steuckart, C., and Kühl, M.: An amperometric microsensor for the determination of $\mathrm{H}_{2} \mathrm{~S}$ in aquatic environments, Anal. Chem., 68, 4351-4357, 1996.

Jørgensen, B. B.: A comparison of methods for the quantification of bacterial sulfate reduction in coastal marine sediments, Geomicrobiol. J., 1, 29-47, 1978.

Jørgensen, B. B., Dunker, R., Grünke, S., and Røy, H.: Filamentous sulfur bacteria, Beggiatoa spp., in arctic marine sediments (Svalbard, 79² ), FEMS Microbiol. Ecol., 73, 500-513, 2010.

Joye, S. B., Boetius, A., Orcutt, B. N., Montoya, J. P., Schulz, H. N., Erickson, M. J., and Lugo, S. K.: The anaerobic oxidation of methane and sulfate reduction in sediments from Gulf of Mexico cold seeps, Chem. Geol., 205, 219-238, 2004.

Judd, A. G., Hovland, M., Dimitrov, L. I., Gil, S. G., and Jukes, V.: The geological methane budget at Continental Margins and its influence on climate change, Geofluids, 2, 109-126, 2002.

Kalanetra, K. M. and Nelson, D. C.: Vacuolate-attached filaments: highly productive Ridgeia piscesae epibionts at the Juan de Fuca hydrothermal vents, Mar. Biol., 157, 791-800, 2010.

Kalanetra, K. M., Joye, S. B., Sunseri, N. R., and Nelson, D. C.: Novel vacuolate sulfur bacteria from the Gulf of Mexico reproduce by reductive division in three dimensions, Environ. Microbiol., 7, 1451-1460, 2005. 
Kallmeyer, J., Ferdelman, T. G., Weber, A., Fossing, H., and Jørgensen, B. B.: A cold chromium distillation procedure for radiolabeled sulfide applied to sulfate reduction measurements, Limnol. Oceanogr.-Meth., 2, 171-180, 2004.

Kjerfve, B., Schettini, C. A. F., Knoppers, B., Lessa, G., and Ferreira, H. O.: Hydrology and salt balance in a large, hypersaline coastal lagoon: Lagoa de Araruama, Brazil, Estuar. Coast. Shelf S., 42, 701-725, 1996.

Kojima, H. and Fukui, M.: Phylogenetic analysis of Beggiatoa spp. from organic rich sediment of Tokyo Bay, Japan, Water Res., 37, 3216-3223, 2003.

Kojima, H., Koizumi, Y., and Fukui, M.: Community structure of bacteria associated with sheaths of freshwater and brackish Thioploca species, Microb. Ecol., 52, 765-773, 2006.

Lanzén, A., Jørgensen, S. L., Bengtsson, M. M., Jonassen, I., Øvreås, L., and Urich, T.: Exploring the composition and diversity of microbial communities at the Jan Mayen hydrothermal vent field using RNA and DNA, FEMS Microb. Ecol., 77, 577589, 2011

Larkin, J. M. and Henk, M. C.: Filamentous sulfide-oxidizing bacteria at hydrocarbon seeps of the Gulf of Mexico, Microsc. Res. Techniq., 33, 23-31, 1996.

Lavik, G., Stührmann, T., Brüchert, V., Van der Plas, A., Mohrholz, V., Lam, P., Mußmann, M., Fuchs, B. M., Amann, R., Lass, U., and Kuypers, M. M. M.: Detoxification of sulphidic African shelf waters by blooming chemolithotrophs, Nature, 457, 581-584, 2009.

Levin, L. A. and Dayton, P. K.: Ecological theory and continental margins: where shallow meets deep, Trends Ecol. Evol., 24, 606617, 2009.

Lichtschlag, A., Felden, J., Brüchert, V., Boetius, A., and de Beer, D.: Geochemical processes and chemosynthetic primary production in different thiotrophic mats of the Håkon Mosby mud volcano (Barents Sea), Limnol. Oceanogr., 55, 931-949, 2010.

Lösekann, T., Knittel, K., Nadalig, T., Fuchs, B., Niemann, H., Boetius, A., and Amann, R.: Diversity and abundance of aerobic and anaerobic methane oxidizers at the Haakon Mosby Mud Volcano, Barents Sea, Appl. Environ. Microbiol., 73, 3348-3362, 2007.

Macalady, J. L., Dattagupta, S., Schaperdoth, I., Jones, D. S., Druschel, G. K., and Eastman, D.: Niche differentiation among sulfur-oxidizing bacterial populations in cave waters, ISME J., 2, 590-601, 2008.

McHatton, S. C., Barry, J. P., Jannasch, H. W., and Nelson, D. C.: High nitrate concentrations in vacuolate, autotrophic marine $\mathrm{Beg}$ giatoa spp., Appl. Environ. Microbiol., 62, 954-958, 1996.

Milkov, A. V.: Worldwide distribution of submarine mud volcanoes and associated gas hydrates, Mar. Geol., 167, 29-42, 2000.

Mills, H. J., Martinez, R. J., Story, S., and Sobecky, P. A.: Identification of members of the metabolically active microbial populations associated with Beggiatoa species mat communities from Gulf of Mexico cold-seep sediments, Appl. Environ. Microbiol., 70, 5447-5458, 2004.

Møller, M. M., Nielsen, L. P., and Jørgensen, B. B.: Oxygen responses and mat formation by Beggiatoa spp., Appl. Environ. Microbiol., 50, 373-382, 1985.

Monteiro, P. M. S., van der Plas, A., Mohrholz, V., Mabille, E., Pascall, A., and Joubert, W.: Variability of natural hypoxia and methane in a coastal upwelling system: Oceanic physics or shelf biology?, Geophys. Res. Lett., 33, L16614, doi:10.1029/2006GL026234, 2006.

Nelson, D. C., Waterbury, J. B., and Jannasch, H. W.: Nitrogen fixation and nitrate utilization by marine and freshwater Beggiatoa, Arch. Microbiol., 133, 172-177, 1982.

Nelson, D. C., Jørgensen, B. B., and Revsbech, N. P.: Growth pattern and yield of a chemoautotrophic Beggiatoa sp. in oxygensulfide microgradients, Appl. Environ. Microbiol., 52, 225-233, 1986.

Nelson, D. C., Wirsen, C. O., and Jannasch, H. W.: Characterization of large, autotrophic Beggiatoa spp. abundant at hydrothermal vents of the Guaymas Basin, Appl. Environ. Microbiol., 55, 2909-2917, 1989.

Niemann, H., Lösekann, T., de Beer, D., Elvert, M., Nadalig, T., Knittel, K., Amann, R., Sauter, E. J., Schlüter, M., Klages, M., Foucher, J.-P., and Boetius, A.: Novel microbial communities of the Haakon Mosby mud volcano and their role as a methane sink, Nature, 443, 854-858, 2006.

Nouzé, H., Fabri, M.-C., and Vicking Scientific Party: Vicking cruise report: Cold seeps on the Norwegian margin; associated ecosystem, Ifremer, 2007.

Omoregie, E. O., Mastalerz, V., de Lange, G., Straub, K. L., Kappler, A., Røy, H., Stadnitskaia, A., Foucher, J.-P., and Boetius, A.: Biogeochemistry and community composition of iron- and sulfur-precipitating microbial mats at the Chefren Mud Volcano (Nile Deep Sea Fan, Eastern Mediterranean), Appl. Environ. Microbiol., 74, 3198-3215, 2008.

Omoregie, E. O., Niemann, H., Mastalerz, V., de Lange, G. J., Stadnitskaia, A., Mascle, J., Foucher, J.-P., and Boetius, A.: Microbial methane oxidation and sulfate reduction at cold seeps of the deep Eastern Mediterranean Sea, Mar. Geol., 261, 114-127, 2009.

Pedersen, R. B., Rapp, H. T., Thorseth, I. H., Lilley, M. D., Barriga, F. J. A. S., Baumberger, T., Flesland, K., Fonseca, R., FrühGreen, G. L., and Jorgensen, S. L.: Discovery of a black smoker vent field and vent fauna at the Arctic Mid-Ocean Ridge, Nat. Commun., 1, 126, doi:10.1038/ncomms1124, 2010.

Pernthaler, A., Pernthaler, J., and Amann, R.: Fluorescence in situ hybridization and catalyzed reporter deposition for the identification of marine bacteria, Appl. Environ. Microbiol., 68, 3094 3101, 2002.

Preisler, A., de Beer, D., Lichtschlag, A., Lavik, G., Boetius, A., and Jørgensen, B. B.: Biological and chemical sulfide oxidation in a Beggiatoa inhabited marine sediment, ISME J., 1, 341-353, 2007.

Prokopenko, M. G., Hammond, D. E., Berelson, W. M., Bernhard, J. M., Stott, L., and Douglas, R.: Nitrogen cycling in the sediments of Santa Barbara basin and Eastern Subtropical North Pacific: nitrogen isotopes, diagenesis and possible chemosymbiosis between two lithotrophs (Thioploca and Anammox) - "riding on a glider", Earth. Planet. Sc. Lett., 242, 186-204, 2006.

Ramette, A.: Quantitative community fingerprinting methods for estimating the abundance of operational taxonomic units in natural microbial communities, Appl. Environ. Microbiol., 75, 24952505, 2009.

Revsbech, N. P. and Ward, D. M.: Oxygen microelectrode that is insensitive to medium chemical composition: Use in an acid microbial mat dominated by Cyanidium caldarium, Appl. Environ. Microbiol., 45, 755-759, 1983. 
Roalkvam, I., Jørgensen, S. L., Chen, Y., Stokke, R., Dahle, H., Hocking, W. P., Lanzén, A., Haflidason, H., and Steen, I. H.: New insight into stratification of anaerobic methanotrophs in cold seep sediments, FEMS Microb. Ecol., 78, 233-243, 2011.

Salman, V., Amann, R., Girnth, A.-C., Polerecky, L., Bailey, J. V., Høgslund, Jessen, G., Pantoja, S., and Schulz-Vogt, H. N.: A single-cell sequencing approach to the classification of large, vacuolated sulfur bacteria, Syst. Appl. Microbiol., 34, 243-259, 2011.

Sayama, M., Risgaard-Petersen, N., Nielsen, L. P., Fossing, H., and Christensen, P. B.: Impact of bacterial $\mathrm{NO}_{3}^{-}$transport on sediment biogeochemistry, Appl. Environ. Microbiol., 71, 75757577, 2005.

Schulz, H. N.: The Genus Thiomargarita, in: The Prokaryotes, edited by: Dworkin, M., Falkow, S., Rosenberg, E., Schleifer, K. H., and Stackebrandt, E., New York, Springer, 1156-1163, 2006.

Schulz, H. N. and Schulz, H. D.: Large sulfur bacteria and the formation of phosphorite, Science, 307, 416-418, 2005.

Schulz, H. N., Brinkhoff, T., Ferdelman, T. G., Hernández Mariné, M., Teske, A., and Jørgensen, B. B.: Dense populations of a giant sulfur bacterium in Namibian shelf sediments, Science, 284, 493-495, 1999.

Schwedt, A., Kreutzmann, A.-C., Polerecky, L., and SchulzVogt, H. N.: Sulfur respiration in a marine chemolithoautotrophic Beggiatoa strain, Front. Microbio., 2, 276, doi:210.3389/fmicb.2011.00276, 2012.

Sievert, S. M., Wieringa, E. B. A., Wirsen, C. O., and Taylor, C. D.: Growth and mechanism of filamentous-sulfur formation by Candidatus Arcobacter sulfidicus in opposing oxygen-sulfide gradients, Environ. Microbiol., 9, 271-276, 2007.

Teske, A. and Nelson, D. C.: The Genera Beggiatoa and Thioploca, in: The Prokaryotes, edited by: Dworkin, M., Falkow, S., Rosenberg, E., Schleifer, K. H., and Stackebrandt, E., New York, Springer, 784-810, 2006.
Teske, A., Jørgensen, B. B., and Gallardo, V. A.: Filamentous bacteria inhabiting the sheaths of marine Thioploca spp. on the Chilean continental shelf FEMS Microbiol. Ecol., 68, 164-172, 2009.

Treude, T., Smith, C. R., Wenzhöfer, F., Carney, E., Bernardino, A. F., Hannides, A. K., Krüger, M., and Boetius, A.: Biogeochemistry of a deep-sea whale fall: sulfate reduction, sulfide efflux and methanogenesis, Mar. Ecol. Prog. Ser., 382, 1-21, 2009.

Urakawa, H., Tajima, Y., Numata, Y., and Tsuneda, S.: Low temperature decreases the phylogenetic diversity of ammonia-oxidizing archaea and bacteria in aquarium biofiltration systems, Appl. Environ. Microbiol., 74, 894-900, 2008.

van Dover, C. L., Aharon, P., Bernhard, J. M., Caylor, E., Doerries, M., Flickinger, W., Gilhooly, W., Goffredi, S. K., Knick, K. E., Macko, S. A., Rapoport, S., Raulfs, E. C., Ruppel, C., Salerno, J. L., Seitz, R. D., Sen Gupta, B. K., Shank, T., Turnipseed, M., and Vrijenhoek, R.: Blake Ridge methane seeps: characterization of a soft-sediment, chemosynthetically based ecosystem, Deep-Sea Res. Pt. I, 50, 281-300, 2003.

van Gaever, S., Moodley, L., de Beer, D., and Vanreusel, A.: Meiobenthos at the arctic Håkon Mosby Mud Volcano, with a parental-caring nematode thriving in sulphide-rich sediments, Mar. Ecol. Prog. Ser., 321, 143-155, 2006.

Wang, Z., Brown, J. H., Tang, Z., and Fang, J.: Temperature dependence, spatial scale, and tree species diversity in eastern Asia and North America, Proc. Natl. Acad. Sci. USA, 106, 13388-13392, 2009.

Yamada, R., Kodama, K., Yamakawa, T., Horiguchi, T., and Aoki, I.: Growth and reproductive biology of the small penaeid shrimp Trachysalambria curvirostris in Tokyo Bay, Mar. Biol., 151, 961-971, 2007. 